\title{
Effect of Climate Variability on Yams (Dioscorea spp.) Production in Central and Northern Benin
}

\author{
Fiacre Hermann Adifon ${ }^{1}$, Gilbert Atindogbé2, Daouda Orou Bello ${ }^{1,3}$, Ibouraïman Balogoun ${ }^{1}$, \\ Ibouraïma Yabi ${ }^{4}$, Joseph Dossou ${ }^{5}$, Léonard Ahoton ${ }^{3}$, Aliou Saïdou'
}

\author{
${ }^{1}$ Integrated Soil and Crop Management (ISCM) Unit, Soil Sciences Laboratory, School of Plant Production Sciences and \\ Techniques, Faculty of Agronomic Sciences, University of Abomey-Calavi, Cotonou, Benin \\ ${ }^{2}$ Laboratory of Study and Research in Applied and Biometric Statistics (LERSAB), Faculty of Agronomic Sciences (FSA) of the \\ University of Abomey-Calavi, Cotonou, Benin \\ ${ }^{3}$ Plant Biology Laboratory, School of Plant Production Sciences and Techniques, Faculty of Agronomic Sciences, University of \\ Abomey-Calavi, Cotonou, Benin \\ ${ }^{4}$ Pierre PAGNEY Laboratory “Climate, Water, Ecosystem and Development”, University of Abomey-Calavi, Faculty of Letters, \\ Arts and Human Sciences, Department of Geography and Spatial Planning, Cotonou, Benin \\ ${ }^{5}$ Laboratory of Bioengineering of Food Processes (LABIOPA), Faculty of Agronomic Sciences (FSA), University of \\ Abomey-Calavi, Cotonou, Benin \\ Email: *adifonf@yahoo.fr
}

How to cite this paper: Adifon, F. H., Atindogbé, G., Bello, D. O., Balogoun, I., Yabi, I., Dossou, J., Ahoton, L., \& Saïdou, A. (2020). Effect of Climate Variability on Yams (Dioscorea spp.) Production in Central and Northern Benin. American Journal of Climate Change, 9, 423-440. https://doi.org/10.4236/ajcc.2020.94027

Received: September 10, 2020 Accepted: December 19, 2020 Published: December 22, 2020

Copyright $\odot 2020$ by author(s) and Scientific Research Publishing Inc. This work is licensed under the Creative Commons Attribution International License (CC BY 4.0).

http://creativecommons.org/licenses/by/4.0/ (c) (i) Open Access

\begin{abstract}
Climate change poses an important constraint to agricultural sector and food security in tropical African countries dominated by rain-fed agriculture. This research focuses on the effects of climate variability on yam production in central and northern Benin. Daily climate data such as temperatures, precipitation, potential evapotranspiration, relative humidity and insolation from 1981 to 2016 were collected at the direction of METEO-Benin. A survey was then conducted with 351 producers to collect their perceptions of the effect of climate variability on the yams production. Descriptive statistics, principal component analysis (PCA) followed by trend analyses, Lamb index calculations and the agro-climatic stress index were carried out. The distribution of rain during the yam cycle (91.5\% of those surveyed), the ambient temperature (84.9\%), insolation (83.5\%), the amount of rainwater that fell during the rainy season $(82.2 \%)$ and the harmattan $(53.3 \%)$ are perceived by sociolinguistic groups as climatic factors affecting the growth, the tuberization and yield of yams according to the producers. The results indicate an upward trend in temperature over the period 2001 to 2016 in the transition zone $\left(28.4^{\circ} \mathrm{C}\right)$ and in the Northeast $\left(27.76^{\circ} \mathrm{C}\right)$ and over the period from 2001 to 2011 in the North-West of Benin $\left(27.71^{\circ} \mathrm{C}\right)$, where the average annual temperature during these periods is higher than normal $\left(27.82^{\circ} \mathrm{C}\right.$ in the center, $27.44^{\circ} \mathrm{C}$ in the Northeast and $27.42^{\circ} \mathrm{C}$ to the northwest). This research also shows an insta-
\end{abstract}


bility of the rains with a regular decrease in the rainfall in the Centre and the North-East of the country. The agro-climatic stress index (ISA) and above all the annual rainfall constitute the main climatic factors which determine the yield of yam in the various growing areas in Benin. The average annual temperature and that of January in the transition zone, the rains of January and April in the North-East zone and the relative humidity in the North-West zone also probability determine the yield of the yam.

\section{Keywords}

Yam, Climate Variability, Yield, Food Security, Benin

\section{Introduction}

The yam (Dioscorea spp.) constitutes in certain tropical countries of Africa, the Caribbean, Oceania and Latin America, the staple food for more than 500 million people (FAOSTAT, 2017; Adifon et al., 2019). In the West Africa, yam plays a major role in livelihoods and social relations in rural areas (Adeniji et al., 2012; Elijah et al., 2018). In Benin, the yam also occupies a privileged place in eating habits. It represents an important source of carbohydrates and vitamin B6 for the populations mainly those of the regions of the Centre and the North of the country (Loko et al., 2013; Adifon et al., 2019). The yam has also entered the market economy strongly in recent decades and has moved from being a food crop to a cash crop. As a result, it constitutes an important source of monetary income for producers and traders (Floquet et al., 2012).

However, the agricultural sector in Benin remains essentially rain-fed, depending on nature and the climate (Boko et al., 2007). Benin is no exception to these profound changes in the climate. The country has indeed known for 40 years, strong climatic variability characterized by a fluctuation in the period and duration of precipitation, a variation in annual rainfall, an increasingly warm climate, drought, unexpected floods and strong winds (Yabi and Afouda, 2012; Bello et al., 2016). These profound changes in climate according to Boko et al. (2007) and Srivastava et al. (2012) negatively affect plant growth and can have consequences on crop yield levels and agrarian systems (Houssou et al., 2016, Bello et al., 2016). To this end, several researches have been carried out in recent years to assess the effects of climate change and the variability of climate factors on agricultural production, in this case on certain crops, including cereals (Agossou et al., 2012), cashew (Bello, 2018), pineapple (Houssou et al., 2016) and cotton (Katé, 2016), but the impacts of the climate on plants with roots and tubers like yams and their potential adaptation to climate change in Benin are still little studied.

However, according to Vaillant et al. (2005), Marcos et al. (2009) and Uger (2017), growth, vegetative development, tuberization and yams productivity also depend on soil conditions, climate factors and their variability. The present 
study therefore aims to assess the effect of climatic factors on the production of yams in different agro-ecological zones of Benin in the context of climate variability.

\section{Study Area}

The present study was conducted in three different yam production areas in Benin according to the climatic gradient (Figure 1) notably the transitional zone (Bantè and Savalou in the Collins department in Central-Benin), the humid or Sudanese tropical climate (Bemberekè in Borgou Department and Gogounou in Alibori department) and a Sudanese mountain or Atacorian climate in the

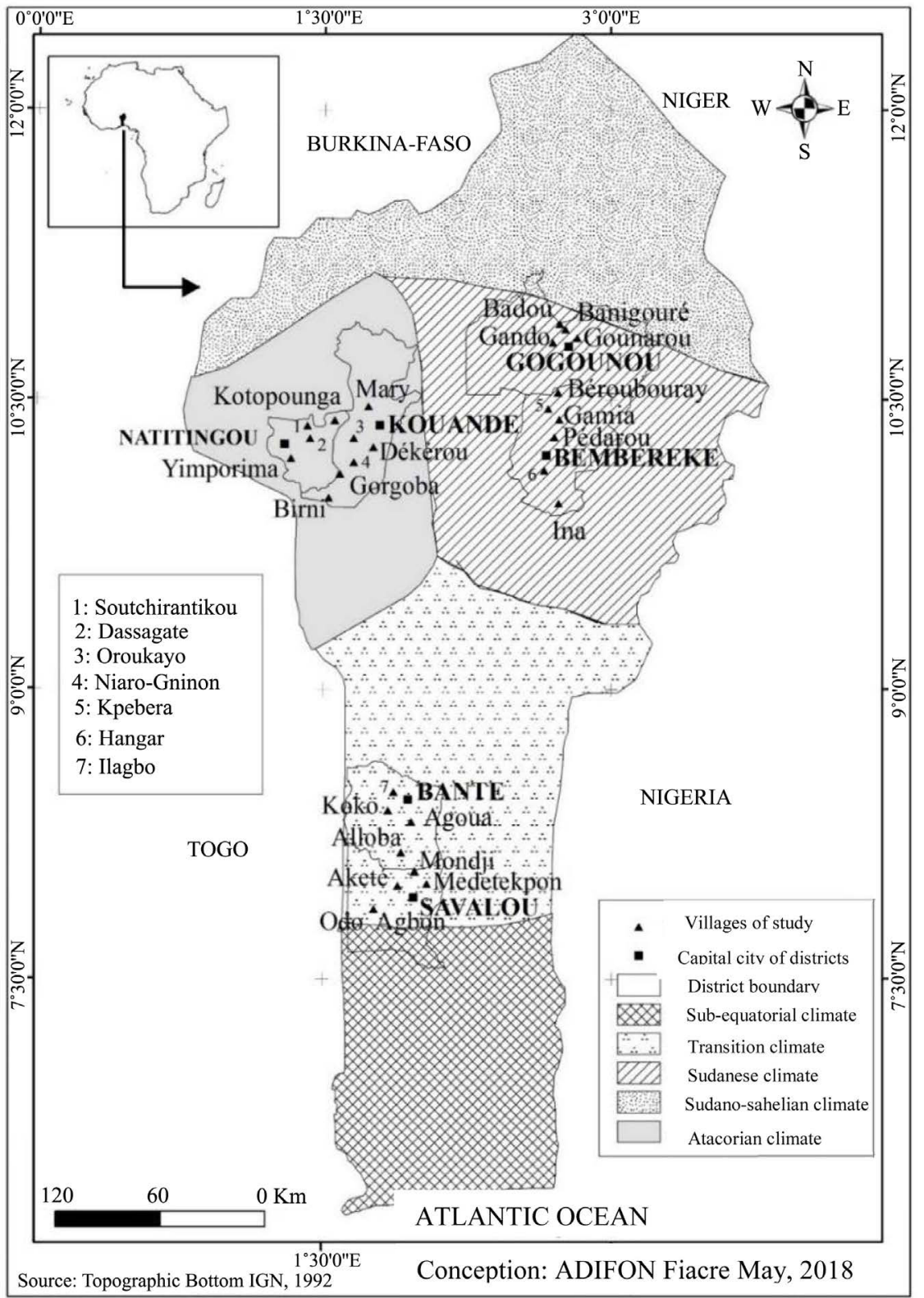

Figure 1. Map of Benin showing the study area. The district's names are in capital letters and the villages names in small letters. 
North-West of Benin (Natitingou and Kouandé in atacora Department). Two seasons, including one rainy from April to October and one dry from November to April, characterize the transition zone which is fairly homogeneous with a peneplain modeled on a Precambrian base and dominated by hills of $300 \mathrm{~m}$ on average (Yabi, 2008). The North-East zone is characterized by a unimodal climate regime with two contrasting seasons including a longer rainy season (from April to October) with 900 to $1300 \mathrm{~mm}$ per year and a slightly shorter dry season, between November to March (Le Lay and Galle, 2005; Lawin, 2007). The North West area is dominated by two seasons, including a rainy one which extends from May to October and a dry one from November to May. Precipitation actually sets in June (Lawin, 2007).

\section{Material and Methods}

\subsection{Data Collection}

Daily climatic data: temperatures (maximum and minimum), rainfall, relative humidity (maximum and minimum), insolation and potential evapotranspiration (ETP) from the synoptic stations of Savè (transition zone); Parakou (NorthEast Zone) and Natitingou (North-West Zone) were collected from METEOBenin. These climate data were collected over the period 1981 to 2016. A survey was also conducted with yam producers to collect their perceptions on climatic factors whose variability affects the growth and productivity of yams on the one hand and the production and area sown of yams by farmers from 2012 to 2017 on the other hand. The sample size $(N)$ for the survey was obtained using the normal approximation of the binomial distribution proposed by Dagnelie (1986):

$$
N=\frac{p(1-p)\left(U_{1-\alpha / 2}\right)^{2}}{d^{2}}
$$

with:

$U_{1-\alpha / 2}$ the value of the normal random variable for the probability value of $1-$ $\alpha / 2$, $\alpha$ being the risk of error. For $\alpha=5 \%$, the probability $1-\alpha / 2=0.975$ and we have $U_{1-\alpha / 2}=1.96, p$ is the estimated proportion of people who cultivate yam in the study environment. The margin error of estimation $(d)$ used in this study is $5 \%(1 \% \leq d \leq 15 \%)$. From the $p$-values of the results of the exploratory phase, 351 producers were selected in the study environment on the basis of 114 producers in the Central area, 121 in the Northeast area and 116 in the North West area. They were distributed in the three zones according to agricultural households cultivating the yam (24.1\% in the Centre, $44.5 \%$ in the North-East and $31.4 \%$ in the North-West). In each locality, the people surveyed were identified using simple random sampling.

\subsection{Data Processing and Analysis}

\subsubsection{Processing of Climatological Data}

To reduce errors from data related to the measures and better visualized the dry 
and wet periods, high and low temperatures periods, the Mean standardized anomaly indix (IP) were calculated from the Formula (1):

$$
\mathrm{IP}=\frac{\mathrm{Xi}-\mathrm{Xm}}{\sigma}
$$

With $\mathrm{Xi}(\mathrm{mm})=$ annual rainfall or temperature in $\mathrm{mm}$ or ${ }^{\circ} \mathrm{C}$ respectively, $\mathrm{Xm}(\mathrm{mm})=$ the mean annual rainfall or temperature over the study period (1981-2016), $\sigma$ = standard deviation of annual rainfall totals or annual mean temperature over the study period. Similarly, in order to study the stationary characters of the time series from 1981 to 2016 for each of the climatic variable per zone, the linear adjustment with the time series analysis, and precisely the trend analysis were performed following the method described by Bowerman and O'Connell (1993). This trend has been assessed taking into account regression equations and determination coefficient $\mathrm{R}^{2}$ (Bello et al., 2016). In order to assess to the periods of the year favorable to the cultivation of yams, the potential monthly water balance was also determined. Its determination took into account the average monthly rainfall and potential evapotranspiration.

- If the potential water balance $<0$; then the period was dry and unfavorable to vegetative activity.

- If the potential water balance $>0$ then moist and conducive to vegetative growth and the tuberization of yams.

\subsubsection{Statistique Analysis of the Data}

The collected data were codified, entered and analyzed using SPSS (Statistical Package for Social Sciences) Version 20.0, for determining descriptive statistics in terms of percentage and mean.

In Benin and generally in Africa, local perceptions of events and practices are influenced by ways and customs, which are dependent on sociocultural groups (Gnanglè et al., 2011). Therefore, the respondents were grouped according to the six main socio-cultural groups, namely Ifè, Itcha, Mahi, Otamari and related in the transition zone, Bariba or Baatonbou and the Peulh in the Sudanian zone in the North East and Bariba, Peulh and Otamari and relatives in the Atacorian zone in the North-West. In each group, respondents were grouped into two age categories (adult i.e. 50 - 70 years, elders, i.e. 70 and above) and sex (Assogbadjo et al., 2008). Thus, in total, 18 socio-cultural categories (instead of 36 potentials) and taking into account the combination of main socio-cultural groups, age and sex were considered (Table 1). For each person surveyed, the perception citation for each indicator of climate change was determined. For each of the 18 categories, an average of perception citation was calculated for each indicator from the average value of the citation of perception of this indicator by the individuals in the group considered. A matrix of perception of indicators of climate change and its effect on the cashew was subjected to Principal Component Analysis (PCA) according to Bello et al. (2017). Statistical analysis was done with Minitab14 software. 
Table 1. Number associated with the 18 main sioco-cultural groups studies $(\mathrm{N}=351)$.

\begin{tabular}{ccc}
\hline socio cultural group & Codes & Number \\
\hline Adults Men Bariba & AMBa & 42 \\
Adults Men Ifè & AMI & 2 \\
Adults Men Itcha & AMIt & 11 \\
Adults Men Mahi; & AMM & 6 \\
Adults Men Otamari & AMOt & 28 \\
Adults Men Peulh & AHPh & 11 \\
Young Women Itcha & YWIt & 3 \\
Young Women Mahi; & YWMa & 1 \\
Young Women Otamari; & YWOt & 1 \\
Young Men Bariba & YMBa & 108 \\
Young Men Ifè & YMI & 10 \\
Young Men Itcha & YMIt & 19 \\
Young Men Mahi & YMMa & 35 \\
Young Men Otamari & YMOt & 53 \\
Young Men Peulh & YMPh & 10 \\
Old Men Bariba & OMBa & 2 \\
Old Men Itcha & OMIt & 6 \\
Old Men Otamari & OMOt & 351 \\
\hline
\end{tabular}

\subsubsection{Investigation of the Dependence between Climatic} Parameters and the Yield of Yams

Yam tubers yields by zone (Transition, North-East and North-West) were calculated on the basis of data collected from producers on the crops and areas sown with yams by year (Adifon et al., 2019). An average value is calculated per year and per zone.

In order to identify among the climatic parameters such as precipitation, temperatures, relative humidity, insolation, the number of rainy days per year and the Agro-climatic Stress Index, those most explanatory of the yield in fresh yam tubers by study area, the econometric approach based on ordinary least squares (OLS) was adopted. This is the multiple linear regression performed using Stata version 14 software. Also, the Fisher test was used to assess to the degree of significance of the information explained by the variables compared to the constant value of each equation.

\section{Results}

\subsection{Farmers' Perception of Climatic Factor Affecting Yam Production in Benin}

The perception of yam producers in the study areas on the effect of climatic factors and their variability on the germination of tubers after planting, the growth 
of the aerial part, the tuberisation and on the productivity of yams are presented in Table 2.

Analysis of this table shows that local perceptions are unanimous on the influence of the variability of climate parameters on the growth and production of yams. The heights of rainwater received during the rainy season $(82.2 \%$ of

Table 2. Proportion (\%) of answers related to the effect of climate components on yam growth and yield according to farmers by climate area.

\begin{tabular}{|c|c|c|c|c|c|}
\hline \multirow[b]{2}{*}{$\begin{array}{l}\text { Climatic } \\
\text { parameters }\end{array}$} & \multirow[b]{2}{*}{ Modality } & \multicolumn{4}{|c|}{ Percentage of responses } \\
\hline & & $\begin{array}{l}\text { Transition } \\
(\mathrm{n}=114)^{1}\end{array}$ & $\begin{array}{l}\text { Northeast } \\
(\mathrm{n}=121)^{1}\end{array}$ & $\begin{array}{l}\text { Northwest } \\
(\mathrm{n}=116)^{1}\end{array}$ & $\begin{array}{c}\text { Total } \\
(\mathrm{N}=351)^{1}\end{array}$ \\
\hline \multirow{2}{*}{$\begin{array}{l}\text { Amount of rainfall } \\
\text { (precipitation or } \\
\text { annual rainfall) }\end{array}$} & $\begin{array}{l}\text { Effect on the growth } \\
\text { and yield of yams }\end{array}$ & 81.6 & 86.8 & 78.4 & 82.3 \\
\hline & $\begin{array}{l}\text { Has no or very little effect } \\
\text { on yam growth and yield }\end{array}$ & 18.4 & 13.2 & 21.6 & 17.7 \\
\hline \multirow{2}{*}{$\begin{array}{l}\text { Length of the } \\
\text { rainy season }\end{array}$} & $\begin{array}{l}\text { Effect on the growth } \\
\text { and yield of yams }\end{array}$ & 90.4 & 92.6 & 88.6 & 90.6 \\
\hline & $\begin{array}{l}\text { Has no or very little effect } \\
\text { on yam growth and yield }\end{array}$ & 9.6 & 7.4 & 11.2 & 9.4 \\
\hline \multirow{2}{*}{$\begin{array}{l}\text { Rainfall } \\
\text { distribution } \\
\text { during the } \\
\text { rainy season }\end{array}$} & $\begin{array}{l}\text { Effect on the growth and } \\
\text { yield of yams }\end{array}$ & 90.4 & 99.2 & 84.5 & 91.5 \\
\hline & $\begin{array}{l}\text { Has no or very little effect } \\
\text { on yam growth and yield }\end{array}$ & 9.6 & 0.8 & 15.5 & 8.5 \\
\hline \multirow{2}{*}{$\begin{array}{l}\text { Duration of the } \\
\text { dry season }\end{array}$} & $\begin{array}{l}\text { Effect on the growth and } \\
\text { yield of yams }\end{array}$ & 71.9 & 91.7 & 83.6 & 82.6 \\
\hline & $\begin{array}{l}\text { Has no or very little effect } \\
\text { on yam growth and yield }\end{array}$ & 28.1 & 8.3 & 16.4 & 17.4 \\
\hline \multirow{2}{*}{ Temperature } & $\begin{array}{l}\text { Effect on the growth and } \\
\text { yield of yams }\end{array}$ & 77.2 & 95.9 & 81 & 84.9 \\
\hline & $\begin{array}{l}\text { Has no or very little effect } \\
\text { on yam growth and yield }\end{array}$ & 22.8 & 4.1 & 19 & 15.1 \\
\hline \multirow{2}{*}{ Insolation } & $\begin{array}{l}\text { Effect on the growth and } \\
\text { yield of yams }\end{array}$ & 77.2 & 93.4 & 79.3 & 83.5 \\
\hline & $\begin{array}{l}\text { Has no or very little effect } \\
\text { on yam growth and yield }\end{array}$ & 22.8 & 6.6 & 20.7 & 16.5 \\
\hline \multirow{2}{*}{ Harmattan } & $\begin{array}{l}\text { Effect on the growth } \\
\text { and yield of yams }\end{array}$ & 62.3 & 57.9 & 39.7 & 53.3 \\
\hline & $\begin{array}{l}\text { Has no or very little effect } \\
\text { on yam growth and yield }\end{array}$ & 37.7 & 42.1 & 60.3 & 46.7 \\
\hline \multirow{2}{*}{ The wind } & $\begin{array}{l}\text { Effect on the growth and } \\
\text { yield of yams }\end{array}$ & 11.4 & 13.2 & 10.3 & 11.7 \\
\hline & $\begin{array}{l}\text { Has no or very little effect } \\
\text { on yam growth and yield }\end{array}$ & 88.6 & 86.8 & 89.7 & 88.3 \\
\hline
\end{tabular}

${ }^{1}$ number of people interviewed. 
people surveyed), the duration of the rainy season during the vegetative cycle of yams (90.6\% of people surveyed), the distribution of rains during the yam cycle (91.5\% of those surveyed), the length of the dry season $(82.6 \%$ of those surveyed), the ambient temperature during the growing cycle of yams $(84.9 \%$ of those surveyed), sunstroke (83.5\%) and harmattan (53.3\%) are thus globally perceived by the interviewers as factors whose fluctuations influence the growth of the aerial part, the tuberization and the yield of yams. The vast majority of producers ( $88.3 \%$ of those surveyed) believe that the speed of the wind, despite its variability, does not affect the growth and yield of yams any more. The results of principal component analysis (PCA) carried out on the perception data made it possible to describe and refine the relations between the sociolinguistic groups, their perceptions of the variability of the climatic parameters and the effects on the growth and the production of yams. These results indicate that the first two axes explain $57.3 \%$ of the total information (Table 3 ).

The projection of the different sociolinguistic groups in the system of axis defined by the climatic parameters (Figure 2) reveals that young women Mahi and Icha, young men and old men Batoonou and adult Peulh men have the perception that sunstroke, the distribution of rain and the dry season during the yam growing cycle are the climate parameters which, the variability affects vegetative
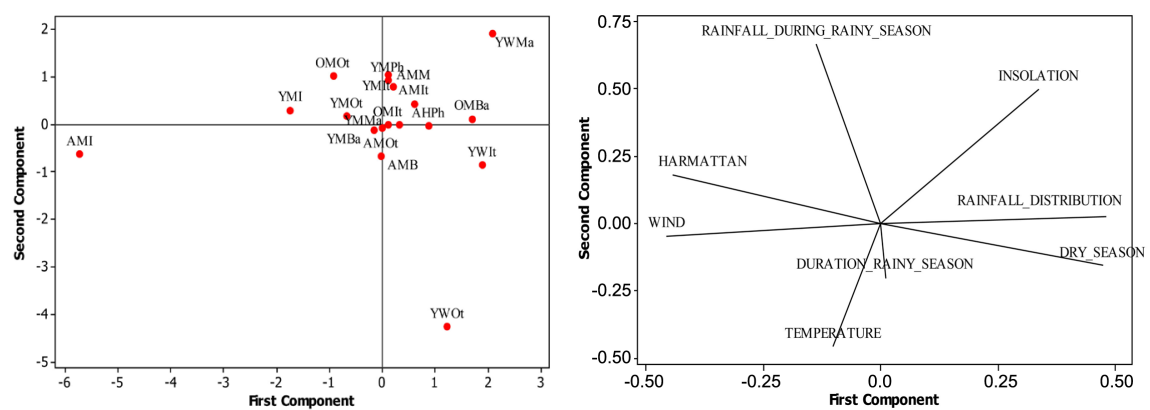

Figure 2. Local perceptions of the effect of climatic parameters on yam production based on Principal Component Analysis (PCA): projection of climatic parameters and socio-cultural groups in the factorial axis system. Legend: $\mathrm{AMB}=$ Adults Men Bariba; AMI $=$ Adults Men Ifè; AMIt = Adults Men Itcha; $\mathrm{AMM}=$ Adults Men Mahi; AMOt $=$ Adults Men Otamari; $\mathrm{AHPh}=$ Adults Men Peulh; YWIt = Young Women Itcha; YWMa = Young Women Mahi; YWOt = Young Women Otamari; YMBa = Young Men Bariba; YMI = Young Men Ifè; YMIt = Young Men Itcha; YMMa = Young Men Mahi; YMOt = Young Men Otamari; YMPh = Young Men Peulh; OMBa = Old Men Bariba; OMIt = Old Men Itcha; OMOt = Old Men Otamari.

Table 3. Eigen value of the four principal components (PC).

\begin{tabular}{cccc}
\hline PC Axis & Eigenvalue & Proportion & Cumulative \\
\hline PC1 & 2.980 & 0.373 & 0.373 \\
PC2 & 1.6022 & 0.2 & $\mathbf{0 . 5 7 3}$ \\
PC3 & 1.3512 & 0.169 & 0.742 \\
PC4 & 0.981 & 0.123 & 0.864 \\
\hline
\end{tabular}


growth and yam production, while for adult men Ife, the harmattan is the climatic factor which variability has more effect on the growing and productivity of yams. For Adult men and Young women Mahi, young men Ifè and Young men peulh, the rains and sunshine are perceived as the climate parameters which variability affects the production of yam.

However, the young women and adult men Otamari and relatives who consider that the variability in temperature and rainfall distribution are the climatic factors that have the greatest impact on yam production in Benin.

\subsection{Trends Analysis of Climatic Parameters in the Study Areas}

The analysis of interannual variability and temperature trends recorded from 1981 to 2016 in synoptic stations near the study areas (Figure 3) shows two different periods. The first period starts from 1981 to 2000 during which the average annual temperature $27.7^{\circ} \mathrm{C}$ in the transition zone, $27.2^{\circ} \mathrm{C}$ in the sudanian zone in the Northeast and $27,3^{\circ} \mathrm{C}$ in the Atacorian zone in the North-West is lower than normal by $27.82^{\circ} \mathrm{C}$ in the Centre, $27.44^{\circ} \mathrm{C}$ in the North-East and $27.42^{\circ} \mathrm{C}$ in the North-West respectively. A second period starts from 2001 to 2016 in the transition and Sudanian zones and 2001 to 2011 in the Atacorian zone and is characterized by an average of the annual temperature above normal with respectively an average temperature over the said period (2001-2016) of $28.4^{\circ} \mathrm{C}$ in the transition zone, $27.76^{\circ} \mathrm{C}$ in the North-East and $27.71^{\circ} \mathrm{C}$ in the North-West of Benin.

The linear regression applied to the thermometric data shows an increasing trend of the ambient temperature in the three zones with a growth rate of $0.07 \%$ in the transition zone, $0.02 \%$ in the Sudanian zone in the North-East and $0.01 \%$ in the Atacorian zone in the northwest. This upward trend in annual average temperatures is fairly linear and very significant $(p<0.05)$ in the transition zone
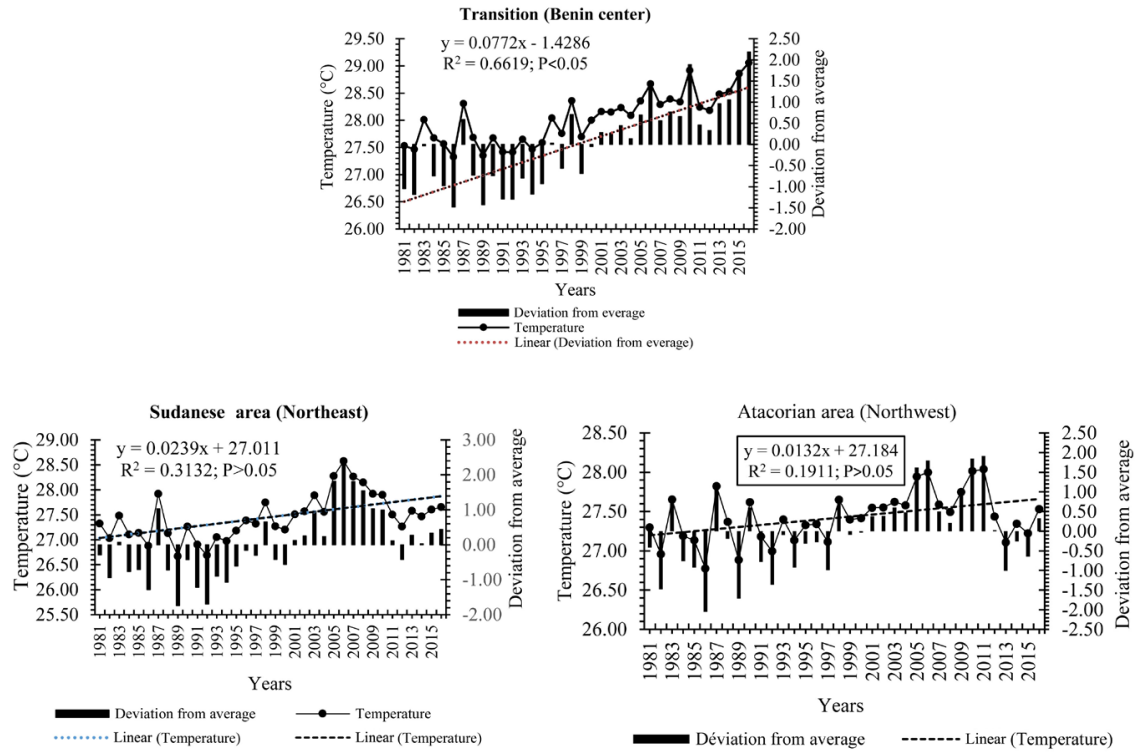

Figure 3. Trend in mean annual temperature in the study areas from 1981-2016. 
with regard to the coefficient of determination $\mathrm{R}^{2}$ in the Centre $\left(\mathrm{R}^{2}=0.68 ; p<\right.$ 0.05).

Similarly, the analysis of the occurrence of maximum daily temperatures by production area (Table 4) reveals that certain months of the year, particularly the months of December, March and April are marked by days when the temperature daily maximum is above $35^{\circ} \mathrm{C}$. In this condition, the availability of water is limited; this can cause water stress with the consequence, a warming followed by rot of the planted tubers or retarded growth of the yam tubers.

Analysis of the average interannual relative humidity recorded at synoptic stations near the study area over the period 1981 to 2016 (Figure 4) shows interannual variations in relative humidity over the entire period study and an increasing trend in the three zones with a growth rate of $0.07 \%$ in the transition zone, $0.05 \%$ in the Sudanian zone against $0.28 \%$ in the Atacorean zone. The average monthly relative humidity is between $50.72 \%$ and $80.05 \%$ in the Centre, $33.61 \%$ and $81.34 \%$ in the North-East and between $30.30 \%$ and $80.65 \%$ in the North-West (Figure 5). The months of December, January, February have the lowest monthly hygrometric values whereas from April to September, the monthly hydrometry values are $69.54 \%$ and $80.06 \%$ in the Center, $63.49 \%$ to $81.31 \%$ in the North-East and $61.35 \%$ to $80.64 \%$ in the North-West.

Analysis of the time series relating to rainfall data shows a high instability of rainfall with a succession of very rainy, moderately rainy, moderately dry, very dry, and extremely dry years (Table 5). Analysis of trends of rainfall (Figure 6) shows a downward trend in the transition and northeast regions with a regression rate ranging from $-1.84 \%$ to $-4.09 \%$ while in the North-west, there is an increasing trend in rainfall. However, these trends in rainfall in the transition zone in the Center and in growth in North-West Benin do not show defined patterns with regard to the coefficients of determination which are very low and
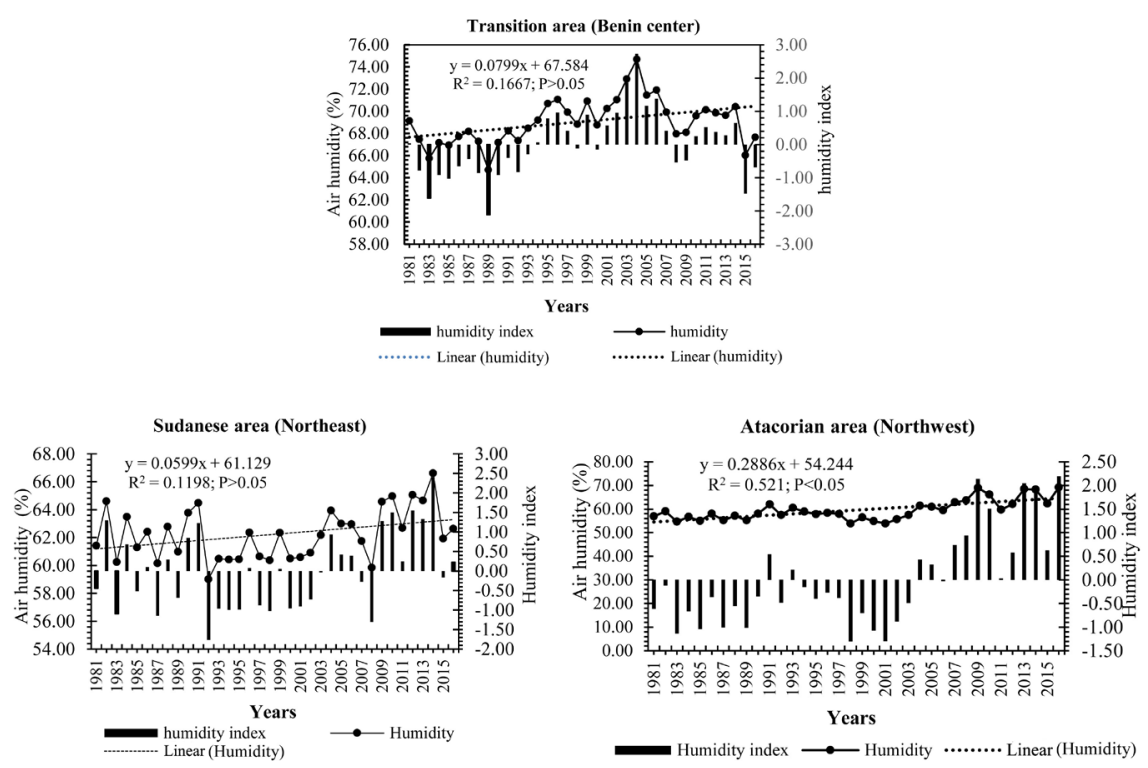

Figure 4. Trend in mean relative humidity in the study areas from 1981 to 2016. 
Table 4. Occurrence of daily maximum temperatures over the period 1981-2016 in the study areas.

\begin{tabular}{|c|c|c|c|c|}
\hline \multirow{2}{*}{$\begin{array}{l}\text { Variables: } \\
\text { Months }\end{array}$} & \multirow{2}{*}{ Modalities } & \multicolumn{3}{|c|}{ Percentage/Number of days } \\
\hline & & Transition & Northeast & Northwest \\
\hline \multirow{3}{*}{ January } & Number of days $\mathrm{T}<35^{\circ} \mathrm{C}$ & 19.9 & 35.5 & 45.2 \\
\hline & Number of days $\mathrm{T}=35^{\circ} \mathrm{C}$ & 32.5 & 38.7 & 32.3 \\
\hline & Number of days $\mathrm{T}>35^{\circ} \mathrm{C}$ & 54.8 & 25.8 & 22.6 \\
\hline \multirow{3}{*}{ February } & Number of days $\mathrm{T}<35^{\circ} \mathrm{C}$ & 0 & 0 & 3.2 \\
\hline & Number of days $\mathrm{T}=35^{\circ} \mathrm{C}$ & 3.2 & 12.9 & 6.5 \\
\hline & Number of days $\mathrm{T}>35^{\circ} \mathrm{C}$ & 96.8 & 87.1 & 90.3 \\
\hline \multirow{3}{*}{ March } & Number of days $\mathrm{T}<35^{\circ} \mathrm{C}$ & 0 & 0 & 0 \\
\hline & Number of days $\mathrm{T}=35^{\circ} \mathrm{C}$ & 12.9 & 3.2 & 0 \\
\hline & Number of days $\mathrm{T}>35^{\circ} \mathrm{C}$ & 87.1 & 96.8 & 100 \\
\hline \multirow{3}{*}{ April } & Number of days $\mathrm{T}<35^{\circ} \mathrm{C}$ & 61.3 & 12.9 & 0 \\
\hline & Number of days $\mathrm{T}=35^{\circ} \mathrm{C}$ & 9.7 & 45 & 16.1 \\
\hline & Number of days $\mathrm{T}>35^{\circ} \mathrm{C}$ & 29 & 41.9 & 83.9 \\
\hline \multirow{3}{*}{ May } & Number of days $\mathrm{T}<35^{\circ} \mathrm{C}$ & 96.8 & 87.1 & 74.9 \\
\hline & Number of days $\mathrm{T}=35^{\circ} \mathrm{C}$ & 0 & 9.7 & 19.4 \\
\hline & Number of days $\mathrm{T}>35^{\circ} \mathrm{C}$ & 3.2 & 3.2 & 6.5 \\
\hline \multirow{3}{*}{ June } & Number of days $\mathrm{T}<35^{\circ} \mathrm{C}$ & 100 & 100 & 100 \\
\hline & Number of days $\mathrm{T}=35^{\circ} \mathrm{C}$ & 0 & 0 & 0 \\
\hline & Number of days $\mathrm{T}>35^{\circ} \mathrm{C}$ & 0 & 0 & 0 \\
\hline \multirow{3}{*}{ July } & Number of days $\mathrm{T}<35^{\circ} \mathrm{C}$ & 100 & 100 & 100 \\
\hline & Number of days $\mathrm{T}=35^{\circ} \mathrm{C}$ & 0 & 0 & 0 \\
\hline & Number of days $\mathrm{T}>35^{\circ} \mathrm{C}$ & 0 & 0 & 0 \\
\hline \multirow{3}{*}{ August } & Number of days $\mathrm{T}<35^{\circ} \mathrm{C}$ & 100 & 100 & 100 \\
\hline & Number of days $\mathrm{T}=35^{\circ} \mathrm{C}$ & 0 & 0 & 0 \\
\hline & Number of days $\mathrm{T}>35^{\circ} \mathrm{C}$ & 0 & 0 & 0 \\
\hline \multirow{3}{*}{ September } & Number of days $\mathrm{T}<35^{\circ} \mathrm{C}$ & 100 & 100 & 100 \\
\hline & Number of days $\mathrm{T}=35^{\circ} \mathrm{C}$ & 0 & 0 & 0 \\
\hline & Number of days $\mathrm{T}>35^{\circ} \mathrm{C}$ & 0 & 0 & 0 \\
\hline \multirow{3}{*}{ October } & Number of days $\mathrm{T}<35^{\circ} \mathrm{C}$ & 100 & 100 & 96.8 \\
\hline & Number of days $\mathrm{T}=35^{\circ} \mathrm{C}$ & 0 & 0 & 3.2 \\
\hline & Number of days $\mathrm{T}>35^{\circ} \mathrm{C}$ & 0 & 0 & 0 \\
\hline \multirow{3}{*}{ November } & Number of days $\mathrm{T}<35^{\circ} \mathrm{C}$ & 41.9 & 54.8 & 16.5 \\
\hline & Number of days $\mathrm{T}=35^{\circ} \mathrm{C}$ & 35.5 & 32.3 & 45.2 \\
\hline & Number of days $\mathrm{T}>35^{\circ} \mathrm{C}$ & 22.6 & 12.9 & 38.7 \\
\hline
\end{tabular}




\section{Continued}

\begin{tabular}{llllc}
\hline & Number of days $\mathrm{T}<35^{\circ} \mathrm{C}$ & 25.8 & 45.2 & 29 \\
December & Number of days $\mathrm{T}=35^{\circ} \mathrm{C}$ & 22.6 & 32.3 & 41.9 \\
& Number of days $\mathrm{T}>35^{\circ} \mathrm{C}$ & 51.6 & 22.6 & 29 \\
\hline
\end{tabular}

Table 5. Classification of the years following to the combined standard rainfall index (IPS) of Mckee and Ali.

\begin{tabular}{|c|c|c|c|c|}
\hline Transition & Northeast & Northwest & $\begin{array}{l}\text { Year to } \\
\text { date IPS }\end{array}$ & $\begin{array}{c}\text { Characteristics } \\
\text { of the years }\end{array}$ \\
\hline 1999,2003 & 1988 & & $>2$ & $\begin{array}{l}\text { Extreme } \\
\text { humidity }\end{array}$ \\
\hline $\begin{array}{c}1988 ; 1995 ; \\
2004 ; 2007 ; 2008\end{array}$ & $\begin{array}{c}1989 ; 1991 ; \\
1995 ; 2008 ; 2014\end{array}$ & $\begin{array}{c}1991 ; 1998 ; 2003 ; \\
2009 ; 2012\end{array}$ & {$[1 ; 2]$} & Very rainy \\
\hline $\begin{array}{l}\text { 1984; 1985; 1987; } \\
\text { 1989; 2006; } \\
\text { 2010; } 2014\end{array}$ & $\begin{array}{c}1984 ; 1994 ; \\
\text { 1996; 1998; 2004; } \\
2009 ; 2010 ; 2012\end{array}$ & $\begin{array}{l}1986 ; 1994 ; 1995 ; \\
1996 ; 2004 ; 2007 ; \\
2008 ; 2010 ; 2011\end{array}$ & {$[0.25 ; 1]$} & Moderately rainy \\
\hline $\begin{array}{l}1994,1996 ; \\
1997 ; 2002\end{array}$ & $\begin{array}{l}\text { 1985; 1993; 1999; } \\
2000 ; 2003 ; 2007 ;\end{array}$ & $\begin{array}{l}1981 ; 1982 ; \\
1999 ; 2005\end{array}$ & {$[-0.25 ; 0.25]$} & Normal \\
\hline $\begin{array}{l}\text { 1981; 1986; } \\
\text { 1990; 1991; } \\
\text { 1992; 1993; } \\
\text { 2000; 2001; } \\
\text { 2009; 2011; } \\
2012 ; 2013\end{array}$ & $\begin{array}{l}1981 ; 1982 ; \\
19861990 ; \\
1992 ; 1997 ; \\
2002 ; 2006 ; \\
2011 ; 2016\end{array}$ & $\begin{array}{c}\text { 1984; 1987; } \\
\text { 1988; 1989; } \\
\text { 1990; 1992; } \\
\text { 1993; 1997; } \\
\text { 2001; 2002; } \\
2006 ; 2015 ; 2016\end{array}$ & {$[-1 ;-0.25]$} & Moderately dry \\
\hline $\begin{array}{c}1982 ; 1998 ; \\
2005 ; 2015 ; 2016\end{array}$ & $\begin{array}{c}1987 ; 2001 ; \\
2005 ; 2013 ; 2015\end{array}$ & $\begin{array}{l}1985 ; 2000 \\
2013 ; 2014\end{array}$ & IPS $[-2 ;-1]$ & Very dry \\
\hline 1983 & 1983 & 1983 & IPS $<-2$ & Extreme drought \\
\hline
\end{tabular}
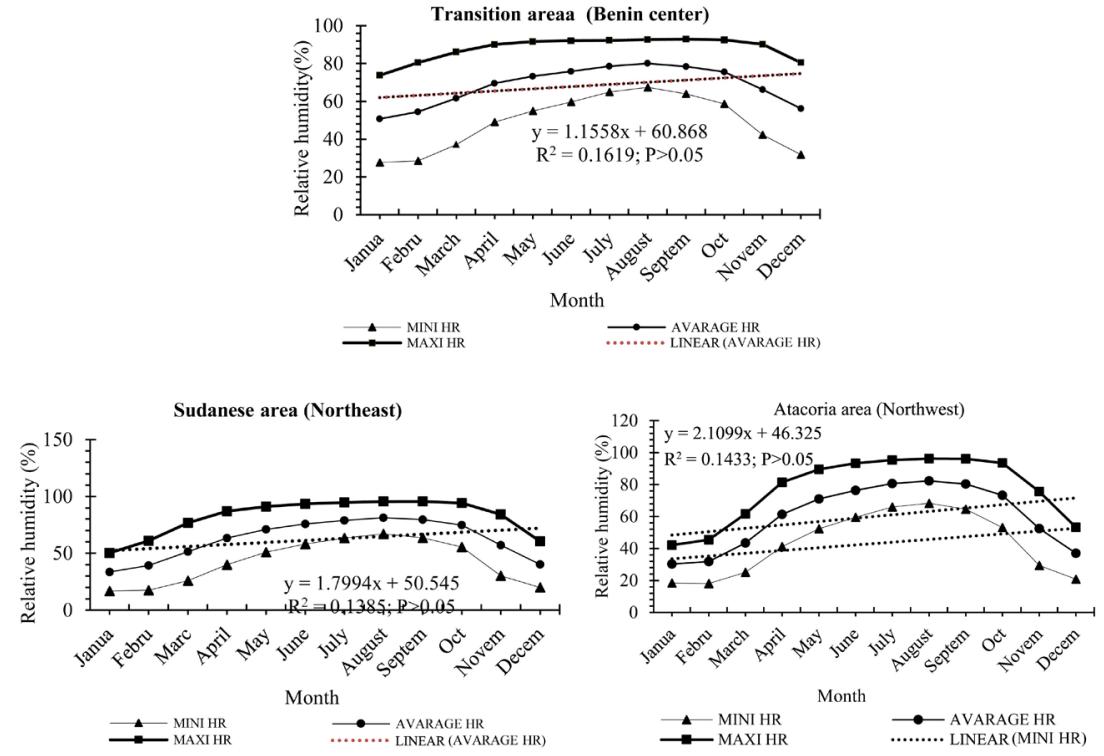

Figure 5. Monthly variations in relative humidity (1981-2016) in the study areas. Legend: MINI HR: Minimum relative humidity; Hmoy: Average relative humidity; MAXI HR: maximum relative humidity. 

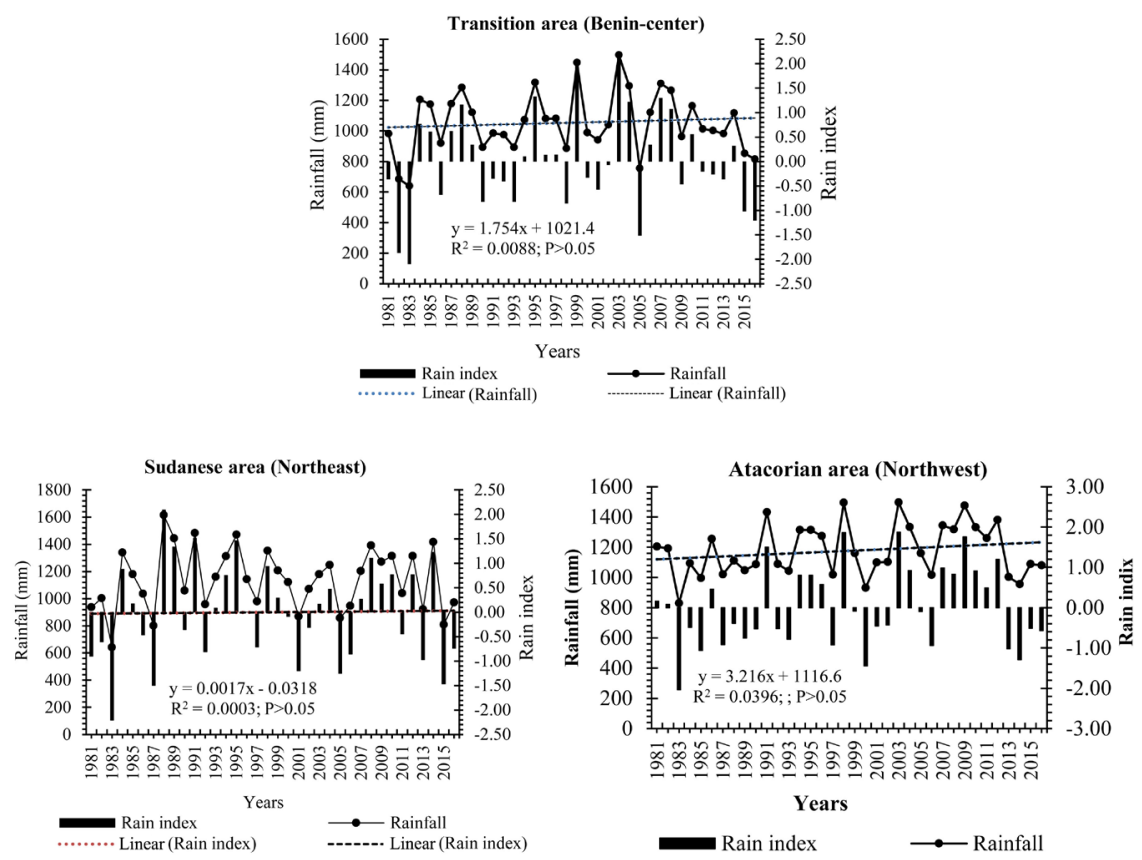

Figure 6. Trend in mean rainfall in the study areas from 1981 to 2016.

not significant $(p>0.05)$. The analysis of the rainfall data and of the potential Evapotranspiration reveals five (5) dry and deficit months in the various zones, in particular the months of January, February, March, November and December. During these rainy months, rainfall remains below FTE and climate demand.

\subsection{Most Determining Climatic Factors for Yam Yield}

The results of the analysis of multiple regressions relating to the most determining climatic parameters of yam yields (Table 6) revealed that the agro-climatic stress index (ISA) and the annual rainfall constitute the main climatic factors which determine the yam yield in the various growing areas in Benin.

The average temperature of January in the transition zone, the rains of January and April in the Sudanian zone as well as the relative humidity and the rains of April in the Atacorian zone also significantly determine the yield of the yam. Likewise, the first rains following the yam planting period, especially in January, especially in the Sudanian zone, probability affect the yield of yams.

\section{Discussion}

The study revealed that the precocity or not of the beginning of the rainy season especially after the emergence outside the mounds of seedlings of planted tubers, the distribution of precipitation during the vegetative cycle, the length of the rainy season, the heights of rainwater received during the rainy season, the dry season throughout its duration, the ambient temperature, the insolation as well as the harmattan are the main climatic factors listed by producers as those whose fluctuations affect production yams in Benin. Several authors such as Agossou et al. (2012) and Bello et al. (2017) in Benin; Ugwoke et al. (2012) in Nigeria, 
Table 6. Linear multiple regression results and their statistical test showing the effect of climatic factors on yam yield in Benin.

\begin{tabular}{|c|c|c|c|c|c|c|}
\hline \multirow{2}{*}{ Variables } & \multicolumn{2}{|c|}{ Transition } & \multicolumn{2}{|c|}{ Northeast } & \multicolumn{2}{|c|}{ Northwest } \\
\hline & Coefficient & Stand-dev. & Coefficient & Stand-dev. & Coefficient & Stand-dev. \\
\hline Constant & 79.3285 & 6.0320 & 10.1009 & 0.4733 & 5.4629 & 0.1159 \\
\hline ASI & $0.0472^{\star * *}$ & 0.0079 & -0.0074 & 0.0071 & $0.1883^{\star * \star}$ & 0.0020 \\
\hline Annual rain & $0.0016^{\star *}$ & 0.0006 & $0.0012^{* * *}$ & 0.0002 & $0.0006^{* * *}$ & 0.0000 \\
\hline April rain & - & - & $0.0045^{\star \star *}$ & 0.0007 & $0.0111^{\star * *}$ & 0.0001 \\
\hline January rain & - & - & $-0.1186^{* * *}$ & 0.0176 & - & - \\
\hline $\begin{array}{c}\text { Annual average } \\
\text { temperature }\end{array}$ & - & - & - & - & - & - \\
\hline $\begin{array}{c}\text { January average } \\
\text { temperature }\end{array}$ & $-0.3312^{* * *}$ & 0.0654 & - & - & - & - \\
\hline $\begin{array}{c}\text { Annual average } \\
\text { humidity }\end{array}$ & - & - & & & $-0.1207^{\star * \star}$ & 0.0014 \\
\hline Value of $F$ & \multicolumn{2}{|c|}{74.37} & \multicolumn{2}{|c|}{22.29} & \multicolumn{2}{|c|}{$20,129.03$} \\
\hline Probability & \multicolumn{2}{|c|}{0.0000} & \multicolumn{2}{|c|}{0.0000} & \multicolumn{2}{|c|}{0.0000} \\
\hline $\mathrm{R}^{2}$ & \multicolumn{2}{|c|}{$82.98 \%$} & \multicolumn{2}{|c|}{$73.38 \%$} & \multicolumn{2}{|c|}{$99.94 \%$} \\
\hline $\mathrm{R}^{2}$ Ajusted & \multicolumn{2}{|c|}{$81.87 \%$} & \multicolumn{2}{|c|}{69.71} & \multicolumn{2}{|c|}{$99.93 \%$} \\
\hline
\end{tabular}

${ }^{* *}$ Correlation significative at $\alpha=0.01 ; * *$ Correlation significative at $\alpha=0.001$.

MacCarthy and Vlek (2012) in Ghana and Bambara et al. (2013) in Burkina Faso have reached similar conclusions on peasant perceptions. According to Bambara et al. (2013), this perception of farmers in tropical regions can be justified by the fact that the climatic variables cited (Rainfall, temperature, insolation and the harmattan) have a direct influence on agricultural production in tropical Africa.

The results of the study also showed that socio-linguistic groups have different perceptions according to sex and age. This results can be explained by the fact, the ability to perceive climate change increased with age and that among rural African communities, men perceive better climate change, probably due to the fact that they are the ones who practice agricultural production the most (Yabi and Afouda, 2012).

In general, the results of the study reveal interannual fluctuations in the various climatic parameters (temperature, rainfall, humidity, evapotranspiration) with an upward trend in temperatures, a regular decrease in rainfall, unpredictable changes in the he arrival of rains in the last 30 years as well as a succession of dry and wet periods in all of the three yam growing areas studied. Many authors have reached similar conclusions in Côte d'Ivoire (Yao N'Guettia et al., 2013), in Ghana (Srivastava et al., 2012) and in Togo (Badjana et al., 2014).

Despite the increase and fluctuation of thermal climatic parameters, the current daily temperatures in the study areas remain fairly close to the optimal temperatures $\left(25^{\circ} \mathrm{C}\right.$ and $\left.30^{\circ} \mathrm{C}\right)$ defined by Shiwachi et al. (2002), Vaillant et al. (2005) and Marcos et al. (2009) for better germination and growth of yams. This means that the thermal values therefore correspond to the acceptable limits for 
yams. These results show that the variability of temperatures in the study area does not significantly affect the production of yams in the transition zone and in the north of Benin. This observation corroborates the findings of Elijah et al. (2018) who showed that climate change has no significant effect on the production of certain root and tuber plants in Cross River State in Nigeria. However, the months of December, January and February which correspond to the sowing or planting period of yams throughout the study area are characterized by daily maximum temperatures above $35^{\circ} \mathrm{C}$ which can delay germination yams, promote rotting, proliferation of pests and affect the productivity of yams. Maximum daily temperatures from December to February may therefore, if the current trend of rising temperatures continue, be detrimental either to the germination of tubers or to the harvest of late-cycle varieties which takes place between December and January. In order to adapt to its very high daily temperatures, farmers are, among other things, shifting the planting periods for yams, shifting production to wet areas (shallows and river beds), making clothes large mounds, deeper seed beds, mulching yam mounds after sowing likewise, the growing preference for yam varieties tolerant to extreme climatic conditions (Ayisounou, Baniouré, Sankounou, Sousounou, Klatchi, Agatou), the increase in planting density and the cultural association are among others strategies developed by yam producers to mitigate the negative effects of climate change. The study found that rainfall is the most crucial climatic parameter for determining the yield of yams in Benin. Similar results have also been obtained by Uger (2017). Since the average annual rainfall in the entire study area is more than $1000 \mathrm{~mm}$, it appears sufficient for good yam production. However, the distribution of precipitation during the cycle is also decisive for obtaining good yields according to Cornet (2015).

The results of the regression analysis of the effect of climatic parameters on the yield of yams also showed that the precipitation that sometimes appears in January in the Sudanian zone negatively affects the yield of yams. This can be explained by the fact that the rains that appear in January favor germination and the emergence of buds. However as soon as new buds emerge from the mounds in the middle of the dry season, the leaves dry out more quickly.

\section{Conclusion}

The results of this research show interannual fluctuations in climatic parameters (temperature, rainfall, humidity, evapotranspiration) in the main yam production areas in Benin with a general rise in interannual temperature over time, a regular decrease in rainfall, unpredictable changes in the onset of the rains in the past 30 years as well as a succession of rainy, moderately rainy, moderately dry, very dry, and extremely dry years in the transition zones, in the Northeast and West Benin. However, the increase and fluctuation of thermal climatic parameters, including temperature, has no significant effect on the production and yield of yams in Benin. Rainfall is the most crucial climatic parameter for determining the yield of yams in Benin. Throughout the study area, this annual rainfall re- 
mains greater than or equal to $1000 \mathrm{~mm}$ and appears sufficient for good yam production despite the distribution of precipitation during the yam vegetative cycle which is very decisive for obtaining better yield.

\section{Acknowledgements}

The authors express their sincere thanks to the DAAD In-Country/In-Region Program for funding this research. They also take the opportunity to thank the authorities at various levels of the University of Abomey-Calavi (UAC) for this partnership with DAAD. Sincere thanks to the reviewers for their important contribution in improving the quality of the manuscript.

\section{Conflicts of Interest}

The authors declare no conflicts of interest regarding the publication of this paper.

\section{References}

Adeniji, O., Adebayo, C., \& Ajayi, O. (2012). Analysis of Marketing Margin of Yam in Selected Rural Areas of Niger State, Nigeria. Basic Research Journal of Agricultural Science and Review, 1, 58-62. http://www.basicresearchjournals.org

Adifon, F. S., Yabi, I., Balogoun, I., Dossou, J., \& Saïdou, A. (2019). Caractérisation socio-économique des systèmes de culture à base d'igname dans trois zones agroécologiques pour une gestion durable des terres au Bénin. European Scientific Journal, 15, 211-232. https://doi.org/10.19044/esj.2019.v15n12p211

Agossou, D. S. M., Tossou, C. R., Vissoh, V. P., \& Agbossou, K. E. (2012). Perception des perturbations climatiques, savoirs locaux et strategies d'adaptation des producteurs agricoles Béninois. African Crop Science Journal, 20, 565-588.

Assogbadjo, A. E., Glèlè kakaï, R., Chadare, F. J., Thomson, L., Kyndt, T., Sinsin, B., \& Van Damme, P. (2008). Folk Classification. Perception and Preferences of Baobab Products in West Africa: Consequences for Species Conservation and Improvement Economic Botany, 62, 74-84. https://doi.org/10.1007/s12231-007-9003-6

Badjana, H. M., Hounkpe, K., Wala, K., Batawila, K., Akpana, K., \& Edjame, K. S. (2014). Analyse de la variabilité temporelle et spatiale des séries climatiques du nord du Togo entre 1960 et 2010. European Scientific Journal, 10, 1857-7881.

Bambara, D., Bilgo, A., Hien, E., Masse, D., Thiombiano, A., \& Hien, V. (2013). Perceptions paysannes des changements climatiques et leurs conséquences socio environnementales à Tougou et Donsin. Climats sahélien et sahélo-soudanien du Burkina Faso. Bulletin de la Recherche Agronomique du Bénin (BRAB), 74, 8-16.

Bello, O. D. (2018). Effect of Climate Change, Genotype-Environment (GxE) Interaction and Adaptation Strategies on Cashew (Anacardium occidentale L) Cultivars Productivity in Benin (198 p.). Thesis of Doctorate in Agronomic Sciences, Godomey: Post Graduate School of Agronomic Sciences, Faculty of Agronomic Sciences, University of Abomey-Calavi.

Bello, O. D., Ahoton, L. E., Saidou, A., Akponikpè, I. P. B., Ezin, V. A., Balogoun, I., \& Aho, N. (2017). Climate Change and Cashew (Anacardium occidentale L.) Productivity in Benin: Perceptions, Endogenous Measures of Adaptation. International Journal of Biological and Chemical Sciences, 11, 924-946. https://doi.org/10.4314/ijbcs.v11i3.1

Bello, O. D., Akponikpè, P. B. I., Ahoton, E. L., Saïdou, A., Ezin, A. V., Kpadonou, G. E., 
Balogoun, I., \& Aho, N. (2016). Trend Analysis of Climate Change and Its Impacts on Cashew Nut Production (Anacardium occidentale L.) in Benin. Octa Journal of Environmental Research, 4, 181-197.

Boko, M., Niang, I., Nyong, A., Vogel, C., Githeko, A., Medany, M., Osman-Elasha, B., Tabo, R., \& Yanda, P. (2007). Climate Change 2007: Impacts, Adaptation and Vulnerability. In M. L. Parry, O. F. Canziani, J. P. Palutikof, P. J. Van Der Linden, \& C. E. Hanson (Eds.), Contribution of Working Group II to the Fourth Assessment Report of the Intergovernmental Panel on Climate Change (pp. 433-467). Cambridge: Cambridge University Press.

Bowerman, B. L., \& O’Connell, R. T. (1993). Forecasting and Time Series: An Applied Approach (3rd ed.). California: Duxbury Press.

Cornet, D. (2015). Influence des premiers stades de croissance sur la variabilité du rendement parcellaire de deux espèces d'igname (Dioscorea spp.) cultivées en Afrique de l'Ouest (174 p.). Thèse de Doctorat unique ès Sciences agronomiques et écologiques, Institut des Sciences et Industries du Vivant et de l'Environnement (AgroParisTech).

Dagnelie, P. (1986). Théorie et méthodes statistiques. Applications Agronomiques (Vol. 2, 463 p.). Les presses agronomiques de Gembloux. A.S.B.L. (Belgium).

Elijah, S. T., Osuafor, O. O., \& Anarah, S. E. (2018). Effects of Climate Change on Yam Production in Cross River State, Nigeria. International Journal of Agriculture and Forestry, $8,104-111$.

FAOSTAT (2017). http://www.fao.org/faostat/en/\#home

Floquet, A., Maliki, R., Tossou, R. C., \& Tokpa, C. (2012). Évolution des systèmes de production de l'igname dans la zone soudano-guinéenne du Bénin. Cahiers Agricultures, 21, 427-437. https://doi.org/10.1684/agr.2012.0597

Gnanglè, P. C., Glèlè Kakaï, R. L., Assogbadjo, A. E., Vodounon, S., Yabi, J. A., \& Sokpon, N. (2011). Tendances climatiques passées, modélisation, perceptions et adaptations locales au Bénin. Climatologie, 8, 26-40. https://doi.org/10.4267/climatologie.259

Houssou, V. M. C., Hounsou, B. M., Ulrich, C. S., Allé, Y., Houssou, S. C., \& Agbossou, K. E. (2016). Variabilité pluviométrique et impact sur le bilan hydrique des sols sous culture d'ananas au Sud-Bénin. International Journal of Innovation and Applied Studies, 15, 830-845.

Katé, S. (2016). Déterminants biophysiques et socio-économiques de l'adaptation aux changements climatiques en zone agro-pastorale de production cotonnière dans la commune de Banikoara (175 p.). Thèse de Doctorat, Université d'Abomey-Calavi, Faculté des Sciences Agronomiques, Département Aménagement et Gestion des Ressources Naturelles.

Lawin, A. (2007). Analyse climatologique et statistique du régime pluviométrique de la Haute Vallée de l'Ouémé à partir des données pluviographiques AMMA-CATCH Bénin (231 p.). Thèse de Doctorat, Institut National Polytechnique de Grenoble, France.

Le Lay, M., \& Galle, S. (2005). Variabilité interannuelle et intra-saisonnière des pluies aux échelles hydrologiques. La mousson ouest-africaine en climat soudanien. Journal des Sciences Hydrologiques, 50, 509-524. https://doi.org/10.1623/hysj.50.3.509.65029

Loko, Y. L., Dansi, A., Agre, A. P., Akpa, N., Dossou-Amin, I., Assogba, P., Dansi, M., Akpagana, K., \& Sanni, A. (2013). Perceptions paysannes et impacts des changements climatiques sur la production et la diversité variétale de l'igname dans la zone aride du nord-ouest du Bénin. International Journal of Biologie and Chemical Science, 7, 672-695. https://doi.org/10.4314/ijbcs.v7i2.23

MacCarthy, D. S., \& Vlek, P. L. G. (2012). Impact of Climate Change on Sorghum Pro- 
duction under Different Nutrient and Crop Residue Management in Semi-Arid Region of Ghana: A Modeling Perspective. African Crop Science Journal, 20, 243-259.

Marcos, J., Lacointe, A., Tournebize, R., Bonhomme, R., \& Sierra, J. (2009). Water Yam (Dioscorea alata L.) Development as Affected by Photoperiod and Temperature: Experiment and Modeling. Field Crops Research, 111, 262-268. https://doi.org/10.1016/j.fcr.2009.01.002

Shiwachi, H., Ayankanmi, T., \& Asiedu, R. (2002). Effect of Day Length on the Development of Tubers in Yam (Dioscorea spp.). Tropical Science, 42, 162.

Srivastava, A. K., Gaisera, T., Paethb, H., \& Ewertc, F. (2012). The Impact of Climate Change on Yam (Dioscorea alata) Yield in the Savanna Zone of West Africa. Agriculture Ecosystems \& Environment, 153, 57-64. https://doi.org/10.1016/j.agee.2012.03.004

Uger, F. I. (2017). Impact de la variabilité climatique sur la production d'igname à Benue Etat: Une analyse empirique. International Journal of Innovative Research in Social Sciences \& Strategic Management Techniques, 4, 10 p.

Ugwoke, F. O., Nnadi, F. N., Anaeto, C. F., Aja, O. O., \& Nwakwasi, R. N. (2012). Crop Farmers' Perception of and Adaptation to Climate Change in Orlu Agricultural Zone of Imo State, Nigeria. Journal of Agricultural Extension, 16, 212-224.

https://doi.org/10.4314/jae.v16i2.16

Vaillant, V., Bade, P., \& Constant, C. (2005). Photoperiod Affects the Growth and Development of Yam Plantlets Obtained by in Vitro Propagation. Biologia Plantarum, 49, 355-359. https://doi.org/10.1007/s10535-005-0007-8

Yabi, I. (2008). Etude de l'agroforesterie à base de l'anacardier et des contraintes climatiques à son développement dans le Centre du Bénin (239 p.). Thèse de Doctorat Unique, Université d'Abomey-Calavi. Ecole Doctorale Pluridisciplinaire Espace, Cultures et Développement.

Yabi, I., \& Afouda, F. (2012). Extreme Rainfall Years in Benin (West Africa). Quaternary International, 262, 39-43. https://doi.org/10.1016/j.quaint.2010.12.010

Yao N’Guettia, R., Oule, A. F., \& N'goran Kouadio, D. (2013). Etude de Vulnérabilité du Secteur Agricole face aux Changements Climatiques En Côte d'Ivoire (105 p.). Ministère de l'Environnement et du Développement Durable, Rapport de PNUD Final. 